\title{
DETERMINATION OF CRITICAL PARAMETERS OF PRODUCTION TECHNOLOGY FOR LESFAL
}

\author{
G.I.Borshchevsky
}

Farmak JSC, Kyiv

Key words: liposomes; technology; critical parameters of production

\begin{abstract}
Currently some success has been achieved when using liposomes in development of new drugs with various actions. Scientists have demonstrated the use of phospholipids as the raw material for production of liposomes. Supercritical fluids are used for producing multilayer, large and small monolayer liposomes. The size and behaviour of liposomes are determined primarily by the presence of a closed membrane wall. As a result, liposomes remain undamaged under various unfavourable conditions, and their membrane is capable to self-regenerate after its structural damages. A positive factor is that flexibility and fluidity of the bilayer give liposomes a high ductility. An important task in development of the liposomal drug technology is to determine the critical parameters that affect obtaining of stable, well characterized liposomal dispersions in large quantities. Critical parameters of the production technology of Lesfal liposomal drug for injection have been determined. It has been found that the most critical step is to obtain a lipid film. The main factors affecting formation of impurities in the process of producing liposomes of Lesfal drug for injection are time; temperature and the vacuum level. The critical parameters for these factors such as time $(45 \mathrm{~min})$, temperature $\left(43^{\circ} \mathrm{C}\right)$, the vacuum level (not less than $14 \mathrm{gPa}$ ) have been determined. They are the optimal values for producing a lipid film for Lesfal liposomes.
\end{abstract}

Currently some success has been achieved when using liposomes in development of new drugs with various actions. Scientists have demonstrated the use of phospholipids as the raw material for production of liposomes $[5,13]$.

As a rule, in the technology of liposomal products a liposome membrane is formed from the same phospholipids found in the composition of biological membranes, i.e. phosphatidylcholine, phosphatidylethanolamine, phosphatidylserine. It allows to achieve complete biocompatibility of liposomes $[3,12]$.

Various methods are used for liposome production. For example, liposomes can be produced by ultrasound, dehydration / rehydration, etc. According to the method of dehydration/rehydration, a lipid is dissolved in an organic solvent (chloroform, dichloromethane, methanol, or ethanol), then the solution is evaporated, for instance, in a rotary evaporator. Water and buffer solution are added to the lipid film formed on the wall of the evaporating flask resulting in multilayer liposomes. Monolayer liposomes are produced by subsequent ultrasonic treatment of the lipid suspension $[6,9,11]$.

Lately, the technology of supercritical fluids has been applied for liposome production. These methods allow producing multilayer, large and small monolayer liposomes. The size and behaviour of liposomes are determined primarily by the presence of a closed membrane wall. Despite the molecular thickness (approximately $4 \mathrm{~nm}$ ), the lipid bilayer is distinguished by the remarkable mechanical strength and flexibility. As a result, liposomes remain undamaged under various unfavourable conditions, and their membrane is capable to self-regenerate after its structural damages. A positive factor is that flexi- bility and fluidity of the bilayer make liposomes highly plastic $[7,8]$.

Taking the above into account an important objective for development of the technology of liposomal drugs is to determine the critical parameters affecting production of stable, well-characterized liposomal dispersions in large quantities [10]. Sterile medicines require particularly serious attitude to ensure quality.

Critical parameters for the technology of a drug for injection using essential phospholipids, which may influence on the strength of the lipid film, and, as a result, on reproducibility from batch to batch, functional characteristics and quality of the product, are:

- the mixing time;

- the rate of the mixer when Lipoid EPCS 100 and excipients are dissolved;

- the $\mathrm{pH}$ of solutions, the quantitative content of phosphatidylcholine, lysophosphatidylcholine and benzyl alcohol;

- the time and storage temperature of the drug solution before bottling;

- temperature at the stages of technological process;

- formulation under the nitrogen atmosphere;

- sterility of the primary package;

- aseptic filling of the drug.

The most critical stage is production of a lipid film [2].

The aim of the work is to determine critical parameters of the production technology of Lesfal liposomal drug for injection.

\section{Materials and Methods}

Ethanol determination was performed by gas chromatography (SPhU, 2.2.28) [4] on an Aglient 7890N gas 


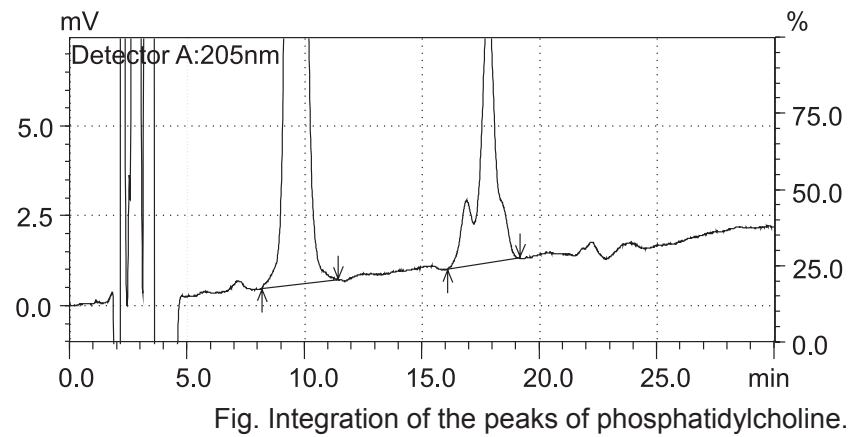

chromatograph with a flame-ionisation detector under the following conditions:

- a HP-INNOWax fused silica capillary column with the size of $30 \mathrm{~m} \times 0.25 \mathrm{~mm}$ covered with a layer of polyethylene glycol with the layer thickness of $0.25 \mu \mathrm{m}$;

- the column temperature: $100^{\circ} \mathrm{C}$;

- the injection temperature: $230^{\circ} \mathrm{C}$;

- the detector temperature: $250^{\circ} \mathrm{C}$;

- the split ratio: $1: 25$;

- the carrier gas: helium for chromatography $R$;

- the flow rate: $0.7 \mathrm{~mL} / \mathrm{min}$.

The content of ethanol in $1 \mathrm{~mL}$ of the drug $\left(\mathrm{X}_{2}\right), \mathrm{mg}$, was calculated using the equation:

$$
X_{2}=\frac{S_{1} \cdot m_{0} \cdot 1 \cdot 10 \cdot P}{S_{0} \cdot 100 \cdot 1 \cdot 10 \cdot 100}=\frac{S_{1} \cdot m_{0} \cdot P}{S_{0} \cdot 10000},
$$

where: $\mathrm{S}_{0}$ - is the average area of the peak of ethanol in the chromatogram obtained with Reference solution (b); $\mathrm{S}_{1}$ - is the average area of the peak of ethanol in the chromatogram obtained with Test solution; $\mathrm{m}_{0}-$ is the weighed amount of ethanol used for preparation of Reference solution (b), mg; $\mathrm{P}$ - is the content of the major substance in ethanol used for preparation of Reference solution (b), $\%$.

Determination of phosphatidylcholine and lysophosphatidylcholine was performed by liquid chromatography (SPhU, 2.2.29) [4] on an Aglient 1200 liquid chromatograph with an ultraviolet detector under the following conditions:

- the steel column with the size of $250 \times 4.6 \mathrm{~mm}$ packed with Kromasil Si sorbent with the particle size of $5 \mu \mathrm{m}$, or equivalent meeting the requirements of the chromatographic system suitability;

- the mobile phase: isopropanol- $n$-hexane-water $R$ (67:16.5:16) ultrasonically degassed;

- the flow rate: $1.0 \mathrm{~mL} / \mathrm{min}$;

- detection: at $205 \mathrm{~nm}$;

- the column temperature: $40^{\circ} \mathrm{C}$;

- the volume of injection: $10 \mu \mathrm{L}$ for determination of phosphatidylcholine; $50 \mu \mathrm{L}$ for determination of lysophosphatidylcholine.

Before the analysis the chromatographic column was equilibrated with the mobile phase in the volume of not less than $300 \mathrm{~mL}$.

Reference solutions (a) and (b) were chromatographed.

The retention time of the peak of phosphatidylcholine is about $10 \mathrm{~min}$; the retention time of the peak of lysophosphatidylcholine is about $18 \mathrm{~min}$. The peaks are integrated as shown in Fig. below.

The chromatographic system is considered to be suitable if:

- the number of theoretical plates calculated by the peak of phosphatidylcholine is not less than 1000;

- the relative standard deviation is not more than $2.0 \%$ calculated for 5 areas of the peak of phosphatidylcholine in the chromatogram obtained with Reference solution (a) and the peak of lysophosphatidylcholine in the chromatogram obtained with Reference solution $(\mathrm{b})$.

The content of lysophosphatidylcholine in $1 \mathrm{~mL}$ of the drug $\left(\mathrm{X}_{4}\right), \mathrm{mg}$, was calculated using equation 2 :

$$
X_{4}=\frac{S_{1} \cdot m_{0} \cdot 50 \cdot P \cdot \rho}{S_{0} \cdot 100 \cdot m_{1} \cdot 100}=\frac{S_{1} \cdot m_{0} \cdot P \cdot \rho}{S_{0} \cdot m_{1} \cdot 200},
$$

where: $\mathrm{S}_{0}$ - is the average area of the peak of lysophosphatidylcholine in the chromatogram obtained with Reference solution (b); $\mathrm{S}_{1}$ - is the average area of the peak of lysophosphatidylcholine in the chromatogram obtained with Test solution; $\mathrm{m}_{0}$ - is the weighed amount of lysophosphatidylcholine used for preparation of Reference solution (b), $\mathrm{mg} ; \mathrm{m}_{1}$ - is the weighed amount of the drug used for preparation of Test solution, $\mathrm{g} ; \mathrm{P}$ - is the content of the major substance in lysophosphatidylcholine used for preparation of Reference solution (b), $\% ; \rho-$ is the density of the drug.

The content of lysophosphatidylcholine per $1 \mathrm{~mL}$ of the drug should be:

- not more than $4 \mathrm{mg}$ at the time of release;

- not more than $6.62 \mathrm{mg}$ on the expiration date.

Evaporation of the alcoholic solution of Lipoid EPCS 100 was performed on a BUCHI rotary evaporator R-215 using the nitrogen blanketing. This rotary evaporator comprises the following major components: a vacuum controller, a flask rotation speed controller and a vapour temperature sensor, a water-bath, a vacuum pump. Temperature and the vacuum level are automatically maintained in the equipment.

\section{Results and Discussion}

During the experiment when evaporating the alcoholic solution of Lipoid EPCS 100 the following parameters were changed: 1 ) the time of evaporation at constant temperature and the vacuum level, 2) the temperature at vacuum of $20 \mathrm{gPa}$ and the time of $45 \mathrm{~min}, 3$ ) the vacuum level at constant temperature and time. The results of the study are presented in Tab. 1, 2, 3.

As shown by the data from Table 1, with the time of evaporation from 35 to $45 \mathrm{~min}$ the content of lysophosphatidylcholine impurity is within the allowed limit range, but the content of ethanol does not comply with the specification. The data from Tab. 2 indicate that the results are best approximated to the optimal ones at the temperature of $43^{\circ} \mathrm{C}$ and the time of $45 \mathrm{~min}$, however, the content of lysophosphatidylcholine is at the upper limit, and the content of ethanol is too high. The required content of impurities in the drug is achieved at the given values of time, temperature, and at the vacuum level of 12 and $14 \mathrm{gPa}$ (Tab. 3). 
Determination of the optimal time for production of a lipid film

\begin{tabular}{|c|c|c|c|c|c|}
\hline $\begin{array}{c}\text { Experiment } \\
\text { No. }\end{array}$ & Temperature, ${ }^{\circ} \mathrm{C}$ & Vacuum, $\mathrm{gPa}$ & Time, min & $\begin{array}{c}\text { Content of impurities } \\
\text { (not more than } 4.0 \mathrm{mg} / \mathrm{mL} \text { ) }\end{array}$ & $\begin{array}{c}\text { Content of ethanol } \\
\text { (not more than } 5.02 \mathrm{mg} / \mathrm{mL} \text { ) }\end{array}$ \\
\hline 1 & 40 & 20 & 35 & 0.8 & 12.6 \\
\hline 2 & 40 & 20 & 40 & 0.9 & 8.5 \\
\hline 3 & 40 & 20 & 45 & 3.6 & 7.7 \\
\hline 4 & 40 & 20 & 50 & 4.7 & 7.2 \\
\hline 5 & 40 & 20 & 60 & 6.4 & 6.3 \\
\hline
\end{tabular}

Table 2

Determination of the optimal temperature for production of a lipid film

\begin{tabular}{|c|c|c|c|c|c|}
\hline $\begin{array}{c}\text { Experiment } \\
\text { No. }\end{array}$ & Temperature, ${ }^{\circ} \mathrm{C}$ & Vacuum, $\mathrm{gPa}$ & Time, min & $\begin{array}{c}\text { Content of impurities } \\
\text { (not more than } 4.0 \mathrm{mg} / \mathrm{mL} \text { ) }\end{array}$ & $\begin{array}{c}\text { Content of ethanol } \\
\text { (not more than } 5.02 \mathrm{mg} / \mathrm{mL} \text { ) }\end{array}$ \\
\hline 1 & 40 & 20 & 45 & 3.6 & 7.7 \\
\hline 2 & 41 & 20 & 45 & 4.0 & 6.7 \\
\hline 3 & 43 & 20 & 45 & 4.0 & 6.5 \\
\hline 4 & 45 & 20 & 45 & 5.8 & 2.0 \\
\hline 5 & 50 & 20 & 45 & 6.5 & 1.1 \\
\hline
\end{tabular}

Table 3

Determination of the optimal vacuum for production of a lipid film

\begin{tabular}{|c|c|c|c|c|c|}
\hline $\begin{array}{c}\text { Experiment } \\
\text { No. }\end{array}$ & Temperature, ${ }^{\circ} \mathrm{C}$ & Vacuum, $\mathrm{gPa}$ & Time, min & $\begin{array}{c}\text { Content of impurities } \\
\text { (not more than } 4.0 \mathrm{mg} / \mathrm{mL} \text { ) }\end{array}$ & $\begin{array}{c}\text { Content of ethanol } \\
\text { (not more than } 5.02 \mathrm{mg} / \mathrm{mL} \text { ) }\end{array}$ \\
\hline 1 & 43 & 20 & 45 & 4.0 & 6.5 \\
\hline 2 & 43 & 18 & 45 & 4.2 & 5.8 \\
\hline 3 & 43 & 16 & 45 & 4.3 & 5.0 \\
\hline 4 & 43 & 14 & 45 & 3.3 & 4.2 \\
\hline 5 & 43 & 12 & 45 & 3.3 & 3.0 \\
\hline
\end{tabular}

Table 4

The optimal parameters for production of a lipid film

\begin{tabular}{|c|c|c|c|c|}
\hline Temperature, ${ }^{\circ} \mathrm{C}$ & $\begin{array}{c}\text { Vacuum, } \mathrm{gPa}, \\
\text { Minimum }\end{array}$ & Time, $\mathrm{min}$ & $\begin{array}{c}\text { Content of impurities } \\
\text { (not more than } 4.0 \mathrm{mg} / \mathrm{mL} \text { ) }\end{array}$ & $\begin{array}{c}\text { Content of ethanol } \\
\text { (not more than } 5.02 \mathrm{mg} / \mathrm{mL} \text { ) }\end{array}$ \\
\hline 43 & 14 & 45 & 3.3 & 4.2 \\
\hline
\end{tabular}

The optimal parameters of production of a lipid film are given in Tab. 4.

Taking into account the physical and chemical properties of Lipoid EPCS the terminal sterilization of the drug is impossible. Sterilization was performed by filtration through a $0.1 \mu \mathrm{m}$ filter, which is acceptable according to the requirements of the $\mathrm{SPhU}$, article Methods of Preparation of Sterile Products. The drug was aseptically filled in the volume of $5.0 \mathrm{~mL}$ into dark-glass ampoules previously blown with sterile nitrogen [1].

The material of ampoules (glass of hydrolytic class 1) was selected according to the requirements of the
SPhU, article 3.2.1 Glass Containers for Pharmaceutical Use.

The preliminary stability study of the drug has confirmed suitability of the primary package.

CONCLUSIONS

1. The major factors that affect formation of impurities when producing liposomes of Lesfal drug for injection are time, temperature and the vacuum level.

2. The critical parameters for these factors such as time ( $45 \mathrm{~min})$, temperature $\left(43^{\circ} \mathrm{C}\right)$, the vacuum level (not less than $14 \mathrm{gPa}$ ) have been determined. They are the optimal values for producing a lipid film for Lesfal liposomes.

\section{REFERENCES}

1. Борщевский Г.И., Омельченко И.О., Скрынский В.С. и др. // Вісник фармації. - 2014. - №1. - С. 39-44.

2. Борщевський Г.І., Комаров І.В., Кулінич А.В. // Управління, економіка та забезпечення якості в фармачії. - 2013. - №6. - C. 10-14. 
3. Водовозова Е.Л., Евдокимов Д.В., Молотковский Юл.Г. // Биоорг. химия. - 2004. - Т. 30, №2. - С. 663.

4. Державна фармакопея Украйни. - Вид. 1. - Х.: РІРЕГ, 2004. - 532 с.

5. Barani H., Montazer M. // J. of Liposome Res. - 2008. - Vol. 8, №3. - P. 249-262.

6. Gomez-Hens A., Fernandez-Romero J.M. // Trends Anal Chem. - 2006. - Vol. 25. - P. 167-178.

7. Kuznetsova N., Kandyba A., Vostrov I. et al. // J. Drug Deliv. Sci. Technol. - 2009. - Vol. 19. - P. 51.

8. Maruyama K. // Biol. Pharm. Bull. - 2000. - Vol. 23. - P. 791-799.

9. Meure L.A., Knott R., Foster N.R. et al. // Langmuir. - 2009. - Vol. 25. - P. 326-337.

10. Mozafari M.R., Johnson C., Hatziantoniou S. et al. // J. of Liposome Res. - 2008. - Vol. 18, №4. - P. 309-327.

11. Torchilin V.P. // Adv. Drug Deliv. Rev. - 2006. - Vol. 1, №58. - P. 1532-1555.

12. Vodovozova E.L., Moiseeva E.V., Grechko G.K. et al. // Eur. J. Cancer. - 2000. - Vol. 36. - P. 942.

13. Zhang L., Gu F.X., Chan J.M. et al. // Clin. Pharmacol. and Therapeutics. - 2008. - Vol. 83, №5. - P. 761-769.

ВИЗНАЧЕННЯ КРИТИЧНИХ ПАРАМЕТРІВ ТЕХНОЛОГІЇ ОТРИМАННЯ ПРЕПАРАТУ «ЛЕСФАЛЬ»

Г.І.Борщевський

Ключові слова: ліпосоми; технологія; критичні параметри виробництва

У теперішній час досягнуті певні успіхи при використанні ліпосом у створенні нових лікарських препаратів різної спрямованості дії. Вченими доведено застосування фросфоліпідів в якості сировини для приготування ліпосом. Найбільш часто для отримання ліпосом використовують технологію надкритичних розчинів. За ї допомогою можна отримати багатошарові, великі і дрібні одношарові ліпосоми. Розміри ліпосом і їх поведінка визначаються, насамперед, наявністю у них замкнутої мембранної оболонки. Внаслідок цього ліпосоми зберігають цілісність при різних несприятливих умовах, а їх мембрана має здатність до самовідновлення при структурних пошкодженнях. Позитивним фрактором $є$ те, що гнучкість бішару $i$ його плинність надають ліпосомам високої пластичності. Важливим завданням при розробці технології ліпосомальних препаратів є визначення критичних параметрів, які впливають на отримання стабільних, добре характеризованих ліпосомальних дисперсій у великих кількостях. Визначені критичні параметри технології отримання ін'єкційного ліпосомального препарату «Лесфраль». Встановлено, що найбільш критичною є стадія отримання ліпідної плівки. Основними фракторами, що впливають на утворення домішок у процесі отримання ліпосом ін'єкційного препарату "Лесфраль», є час; температура і рівень вакууму. Визначені критичні параметри даних фракторів: час $\left(45\right.$ хв), температура $\left(43^{\circ} \mathrm{C}\right)$, величина вакууму (не менше 14 гПа), якіє оптимальними для процесу отримання ліпідної плівки ліпосом препарату «Лесфраль».

\section{ОПРЕДЕЛЕНИЕ КРИТИЧЕСКИХ ПАРАМЕТРОВ ТЕХНОЛОГИИ ПОЛУЧЕНИЯ ПРЕПАРАТА «ЛЕСФАЛЬ" \\ Г.И.Борщевский \\ Ключевые слова: липосомы; технология; критические параметры производства}

В настоящее время достигнуты определенные успехи при использовании липосом в создании новых лекарственных препаратов различной направленности действия. Ученые доказали применение фоосфолипидов в качестве сырья для приготовления липосом. Наиболее часто для получения липосом используют технологию сверхкритических растворов. С её помощью можно получить многослойные, крупные и мелкие однослойные липосомы. Размеры липосом и их поведение определяются, прежде всего, наличием у них замкнутой мембранной оболочки. В результате этого липосомы сохраняют иелостность при различных неблагоприятных условиях, а их мембрана обладает способностью к самовосстановлению при структурных повреждениях. Положительным фрактором является то, что гибкость бислоя и его текучесть придают липосомам высокую пластичность. Важной задачей при разработке технологии липосомальных препаратов является определение критических параметров, влияющих на получение стабильных, хорошо характеризуемых липосомальных дисперсий в больших количествах. Определены критические параметры технологии получения инъекционного липосомального препарата «Лесфаль». Установлено, что наиболее критичной является стадия получения липидной пленки. Основными фракторами, влияющими на образование примесей в процессе получения липосом инъекционного препарата "Лесфраль», являются время; температура и уровень вакуума. Определены критические параметры данных фракторов: время (45 мин), температура $\left(43^{\circ} \mathrm{C}\right)$, уровень вакуума (не менее 14 гПа), которые являются оптимальными для процесса получения липидной пленки липосом препарата «Лесфраль». 